\title{
Xhosa Language
}

National Cancer Institute

\section{Source}

National Cancer Institute. Xhosa Language. NCI Thesaurus. Code C154200.

A Niger-Congo Bantu language spoken as an official language in South Africa and

Zimbabwe. 